\title{
Synthesis of Yeast Wall Glucan
}

\author{
By R. SENTANDREU, M. VICTORIA ELORZA AND J. R. VILLANUEVA \\ Departamento de Microbiologia, Facultad de Ciencias, CSIC \\ Universidad de Salamanca, Spain
}

(Received 22 August 1974)

SUMMARY

Saccharomyces cerevisiae was treated with a mixture of toluene and ethanol to make it permeable to small molecules. This treatment unmasked a glucan synthetase activity which was assayed with UDP-[U-14C]glucose. About $60 \%$ of the polymer formed was $\beta$-( $\mathrm{I} \rightarrow 3)$ glucan. No labelled lipids were detected.

The ${ }^{14} \mathrm{C}$ incorporated was recovered in a particulate membrane preparation isolated by differential centrifugation. When the particles themselves were assayed for glucosyl transfer activity none was found.

The toluene-treated preparations also catalysed the transfer of mannosyl residues from GDP-mannose to polymeric materials by a process independent of glucosyl transfer.

\section{INTRODUCTION}

Yeast wall morphogenesis can be used as a model system for studying the molecular mechanisms that control development in eucaryotic cells.

The major components of the yeast wall are mannan-proteins and $\beta$-linked glucans which are believed to form macromolecular complexes. The walls can be hydrolysed by specific enzymes or hot alkaline solutions. After alkaline treatment, the residual and highly insoluble material, known as yeast glucan, retains the shape of the original cell.

Although there is some information about the chemical structure and biosynthesis of the wall mannan proteins (Sentandreu \& Northcote, 1968; Sentandreu \& Elorza, 1973; Stewart \& Ballou, 1968), and the structure of the yeast glucan has been worked out (Manners, Masson \& Patterson, 1973), little is known about the biosynthesis of the $\beta$-linked glucan. Current speculations postulate that in bacteria (Ghuysen, I968), fungi (Mahadevan \& Mahadkar, 1970) and higher plants (Lamport, 1970), wall construction involves both lytic and biosynthetic activities. Their interaction might result in a controlled extension of the area of the rigid wall, without a significant change in its thickness.

The lytic activities associated with the yeast wall have been studied (Reese, Parrish \& Mandels, I962; Matile et al. I97I; Abd-El-Al \& Phaff, I969; Barras, I972; Johnson, I968). Gachelin (1969), Reeves \& Sols (1973) and Serrano, Gancedo \& Gancedo (I973) have studied several enzyme systems rendered accessible by disruption of the permeability barrier with small amounts of toluene - conditions which have been designated 'in situ' (Reeves \& Sols, I973). We have recently used this technique to study the regulation of the mannosyl transferase system which participates in the biosynthesis of yeast wall mannoproteins (R. Sentandreu, G. Larriba, M. V. Elorza and J. R. Villanueva, unpublished results). Here we show the incorporation of the glucosyl moiety of UDP-glucose into the wall glucan of Saccharomyces cerevisiae. 


\section{METHODS}

Materials. UDP-[U_14 C]glucose (specific activity $260 \mathrm{mCi} / \mathrm{mmol}$ ), GDP-[U-14 $\mathrm{C}] \mathrm{mannose}$ (specific activity $83 \mathrm{mCi} / \mathrm{mmol}$ ) and $\left[\mathrm{U}-{ }^{14} \mathrm{C}\right]$ glucose (specific activity $3 \mathrm{mCi} / \mathrm{mmol}$ ) were obtained from the Radiochemical Centre, Amersham, Buckinghamshire. Concanavalin A was prepared by the method of Agrawal \& Goldstein (1965). Whenever possible other reagents used were of analytical grade.

Organism and media. Saccharomyces cerevisiae LK2GI 2 was obtained from Dr C. Lindegren, Carbondale, Illinois, U.S.A., and grown at 28 to $30^{\circ} \mathrm{C}$, with continuous shaking, to early exponential phase, in a medium containing $3 \mathrm{~g}$ yeast extract and $20 \mathrm{~g}$ glucose/1. The cells were collected by centrifugation and washed with chilled $50 \mathrm{~mm}$-tris-maleate buffer, $\mathrm{pH} \mathrm{6.5.}$

Toluene treatment. The washed cells were suspended in chilled $50 \mathrm{mM}$-tris-maleate buffer, $\mathrm{pH} 6.5$ to a density of $10 \mathrm{mg}$ dry weight $/ \mathrm{ml}$ and mixed with an ethanol-toluene solution $(50 \%, v / v)$ to give a final concentration of $\mathrm{I} \%(\mathrm{v} / \mathrm{v})$. The suspension was shaken for $\mathrm{I} 0 \mathrm{~min}$ with a Whirlimixer. The yeast was then washed free of organic solvents by two centrifugations in buffer and kept in an ice-cold water bath before use.

Incorporation experiments. Toluene-treated suspensions ( $5 \mathrm{mg}$ dry wt) were incubated in $\mathrm{I} .5 \mathrm{ml}$ of $50 \mathrm{mM}$-tris-maleate buffer $\mathrm{pH} 6.5$ containing $10 \mathrm{mM}^{-} \mathrm{MgCl}_{2}$ and UDP-[U-14C] glucose. After $30 \mathrm{~min}$ at $30^{\circ} \mathrm{C}$, the reaction was stopped by the addition of $\mathrm{r} \cdot 5 \mathrm{ml}$ of cold I0 \% trichloroacetic acid (TCA). The precipitates formed were collected on glass fibre discs, washed with $50 \mathrm{ml}$ of cold $5 \%$ TCA, dried, and counted (total incorporation).

Assay of insoluble yeast wall glucan. Radioactivity incorporated into wall glucan was determined after extraction of the preparations first with $2 \mathrm{M}-\mathrm{NaOH}$ at $100{ }^{\circ} \mathrm{C}$ for $2 \mathrm{~h}$, then with $0.5 \mathrm{M}$-acetic acid at $100^{\circ} \mathrm{C}$ for $2 \mathrm{~h}$ (A-A treatment). The insoluble residues were collected on glass fibre discs, washed with distilled water and counted (Sentandreu \& Northcote, 1969).

Radioactivity incorporated into glycogen. Toluene-treated cells (I00 mg dry wt) were labelled with $0 . \mathrm{I}$ or $\mathrm{I} \cdot 0 \mathrm{mM}-\mathrm{UDP}-\left[\mathrm{U}-{ }^{14} \mathrm{C}\right]$ glucose. The radioactivity incorporated into insoluble glucan was estimated (see above). The corresponding materials extracted with $\mathrm{NaOH}$ and with acetic acid were neutralized and concanavalin $\mathrm{A}$ (40 $\mathrm{mg}$ in I $\mathrm{M}-\mathrm{NaCl}$ ) was added. After $2 \mathrm{~h}$ at room temperature the precipitates formed were collected and counted. Radioactivity incorporated into soluble $\beta$-glucan was determined, as TCA-precipitable radioactivity minus (insoluble $\beta$-glucan + glycogen).

Amylase treatment. Portions of the insoluble material collected after alkaline and acid treatment $(2 \mathrm{mg}$ dry wt) were incubated with $2 \mathrm{mg}$ amylase in $50 \mathrm{~mm}$-phosphate buffer $\mathrm{pH} 7 \cdot 8$ at room temperature for $3 \mathrm{~h}$.

Radioactivity incorporated into lipids. Radioactive lipids formed were extracted by shaking the reaction mixture with 20 volumes of chloroform-methanol $(2: \mathrm{I}, \mathrm{v} / \mathrm{v})$ at room temperature for $60 \mathrm{~min}$. The organic extracts were washed with $0.9 \%(\mathrm{w} / \mathrm{v}) \mathrm{NaCl}(0.2 \mathrm{vol}$.), fully dried in a rotary evaporator, and then redissolved in chloroform. The crude lipid preparations were fractionated on silicic acid columns as previously described (Sentandreu \& Lampen, 1971).

Chromatography. Insoluble radiocative $\beta$-glucan $(5 \mathrm{mg})$ was subjected to partial acid hydrolysis (Manners et al. 1973) in sealed ampoules and the hydrolysates were neutralized with Dowex resin $2 \times 8$ (carbonate form). The residual solutions were freeze-dried and samples chromatographed with glucose, laminaribiose and maltose as standards on Whatman No. I paper in ethyl acetate-pyridine-water $(8: 2: 1$, by vol.). Sugars were detected with 
the alkaline $\mathrm{AgNO}_{3}$ reagent. After chromatography the papers were dried, cut into sections $(4 \times \mathrm{I} \mathrm{cm})$ and counted in glass scintillation vials (Sentandreu \& Northcote, 1969).

Experiments on wall turnover. Exponentially-growing cells (Io mg dry wt) were labelled with [U-14 C]glucose $(3 \cdot 75 \mu \mathrm{Ci})$. After $4 \mathrm{~h}$ at $28{ }^{\circ} \mathrm{C}$, the yeast was washed and transferred to $50 \mathrm{ml}$ of a fresh medium without radioactive glucose. Samples (I mg dry wt cells) were collected at $15,30,45,60,75,90$ and $120 \mathrm{~min}$ and the radioactivity associated with glucan and mannan determined (Elorza \& Sentandreu, I969).

\section{RESULTS AND DISCUSSION}

Radioactivity from UDP-[U-14 C]glucose was incorporated by toluenized cells (Table I). The toluene treatment increased the incorporation up to 20-fold. Radioactivity from $\left[\mathrm{U}-{ }^{14} \mathrm{C}\right]$ glucose was not incorporated.

Determination of the total radioactivity incorporated gave no information about the fate of the glucose, which might have formed yeast glycogen ( $\alpha$-glucan) and wall glucan $(\beta-$ glucan). The labelled preparation was therefore extracted with alkali and acid (A-A treatment) as described in Methods. A-A treatment removes wall mannan, glycogen and other soluble compounds (Northcote \& Horne, I95I). The residue comprises $\beta$ - $(\mathrm{I} \rightarrow 3)$ glucan and small amounts of chitin (Manners et al. 1973; Bacon et al. 1969). The A-Atreated residue was further examined as follows. One portion $(2 \mathrm{mg})$ was incubated with $2 \mathrm{mg}$ of amylase in $50 \mathrm{~mm}$-phosphate buffer $\mathrm{pH} 7.8$ at room temperature for $3 \mathrm{~h}$. The insoluble product contained virtually all the radioactivity present before the amylase treatment, thereby indicating the absence of radioactive glycogen. A further portion $(5 \mathrm{mg})$ was incubated with $90 \%(\mathrm{w} / \mathrm{v})$ formic acid for $30 \mathrm{~min}$ followed by $0.17 \mathrm{M}$-sulphuric acid for I h, as described by Manners et al. (1973). Paper chromatography of the solubilized material showed the presence of radioactive substances which co-chromatographed with glucose, laminaribiose and possibly higher laminarisaccharides (Fig. I). There were also small amounts of radioactive material with the $R_{F}$ of maltose, which suggests that glycogen had also been synthesized. This was further confirmed when it was found that $5.2 \%$ of the radioactivity incorporated by the preparation, and solubilized by A-A treatment, subsequently precipitated with concanavalin $A$. These results suggest that at least part of the glucose transferred to endogenous acceptor(s) was incorporated into the $\beta$-(I $\rightarrow 3)$ glucan found in the yeast wall or into its precursors.

Untreated suspensions incorporated small but detectable amounts of glucose from UDP-[U-14 C]glucose (Table I). This suggests that either the sugar donor is hydrolysed to glucose and the free sugar subsequently incorporated, or the enzymic system which transfers the glucosyl residues from UDP-glucose into endogenous acceptor is accessible from outside the plasmalemma.

The $\mathrm{pH}$ value of the medium was varied from $4 \cdot 5$ to $8 \cdot 0$, and the maximal enzymic transfer was obtained at $\mathrm{pH} 6 \cdot 5$.

The influence of several cations and mercaptoethanol on the glucosyl transfer is shown in Table 2. The maximal transfer detected was with $\mathrm{Mg}^{2+}$ in the absence of mercaptoethanol. The rate of incorporation of radioactive glucose was linear for at least $60 \mathrm{~min}$.

\section{Studies with cell fractions}

The subcellular location of the ${ }^{14} \mathrm{C}$ incorporated was studied by differential centrifugation (Fig. 2). About $25 \%$ of the radioactivity was found in the fraction $\mathrm{P}_{2}$, containing mainly walls and some whole cells. The largest amount of label $(64 \%)$ was found in the particulate 


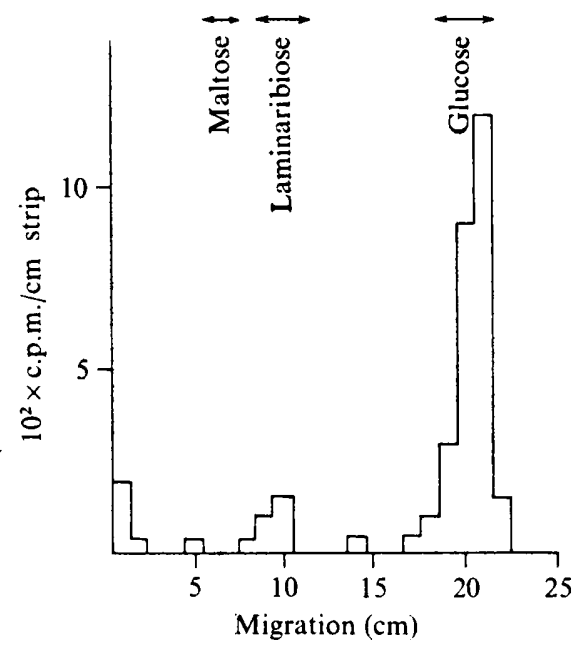

Fig. I.

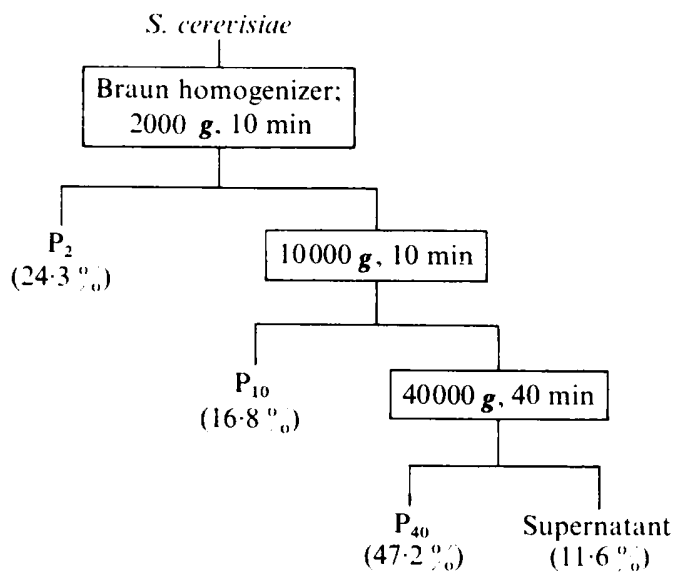

Fig. 2.

Fig. I. Histogram of the radioactivity released by partial acid hydrolysis (Manners et al. 1973) of the glucan residue left after subjecting the ${ }^{14} \mathrm{C}$-labelled toluenized yeast to the $\mathrm{A}-\mathrm{A}$ treatment (see text).

Fig. 2. Transfer of glucose from UDP-[U- $\left.{ }^{14} \mathrm{C}\right] \mathrm{glucose}$ into endogenous acceptor in situ. The toluenetreated preparation $(240 \mathrm{mg})$ labelled with $120 \mathrm{nCi}$ UDP-[U-14 C]glucose $(0.5 \mathrm{nmol})$ was washed, homogenized in a Braun Model MSK mechanical homogenizer, and the suspension fractionated as indicated. Each fraction was treated with I vol. of $10 \%$ TCA and the precipitates counted. The values given below the fractions represent the percentage of the total transfer activity (representing 34,380 c.p.m.) found in that fraction.

\section{Table I. Incorporation of radioactive glucose from $U D P-\left[U-{ }^{14} C\right]$ glucose}

For the conditions used, see Methods.

\begin{tabular}{|c|c|}
\hline pmol & $\mathrm{nCi}$ \\
\hline 90 & 25 \\
\hline 190 & 50 \\
\hline 390 & 100 \\
\hline
\end{tabular}

Glucose incorporated

(pmol/5 mg dry wt yeasts)

$\begin{array}{cc}\text { Toluene-treated cells } & \text { Untreated cells } \\ 4.6 & 0.5 \\ 10.0 & 0.8 \\ 16.0 & 0.8\end{array}$

fractions $\left(\mathrm{P}_{10}\right.$ and $\left.\mathrm{P}_{40}\right)$ which were of intracytoplasmic origin, as can be deduced both from their preparation (Fig. 2) and by electron microscopy (Fig. 3). The presence of radioactivity in fractions $\mathbf{P}_{10}$ and $\mathbf{P}_{\mathbf{4 0}}$ suggested that they might exhibit glucosyl transfer activity. However, the particulate fractions $\left(\mathrm{P}_{10}+\mathrm{P}_{40}\right)$ incorporated no label into the TCA-insoluble fractions, whereas parallel tests with the preparation in situ, using either $0 . \mathrm{I}$ or $\mathrm{I} \cdot 0 \mathrm{mM}$ UDP-[U- $\left.{ }^{14} \mathrm{C}\right]$ glucose, gave results like those described above. About $35 \%$ of the radioactive glucose incorporated was extracted by the A-A treatment. Because 4 to $5 \%$ of the extracted material was precipitated by concanavalin A we infer that some radioactivity had been incorporated into glycogen.

The soluble radioactivity that was not precipitated ( 29 to $31 \%$ ) may have been incorporated into low molecular weight $\beta$-glucan. This is solubilized by the A-A treatment (Manners et al. 1973) and is not precipitated by concanavalin $A$. 
Table 2. Effect of selected cations and of mercaptoethanol on the incorporation of radioactivity from $U D P-\left(U-{ }^{14} C\right)$ glucose

The toluene-treated yeast $(5 \mathrm{mg})$ was incubated at $30{ }^{\circ} \mathrm{C}$ for $30 \mathrm{~min}$ in $50 \mathrm{~mm}$-tris-maleate buffer, $\mathrm{pH} 6.5$, containing UDP-glucose $(25 \mathrm{pmol})$, the indicated cations (IO mM) and mercaptoethanol (I $\mathrm{mM}$ ).

$\quad \begin{aligned} & \text { Incubation } \\ & \text { conditions }\end{aligned}$
Buffer
$+\mathrm{Mg}^{2+}$
$+\mathrm{Mn}^{2+}$
$+\mathrm{Co}^{2+}$
$+\mathrm{Fe}^{2+}$
$+\mathrm{K}^{+}$

Buffer

$+\mathrm{Mg}^{2+}$

$+\mathrm{Mg}^{2+}+$ mercaptoethanol

$+\mathrm{Mn}^{2+}$

$+\mathrm{Mn}^{2+}+$ mercaptoethanol

\section{Glucose incorporated (pmol/5 mg yeast)}

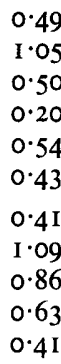

Percentage of control

100
205
100
41
110
88
100
221
173
129
100

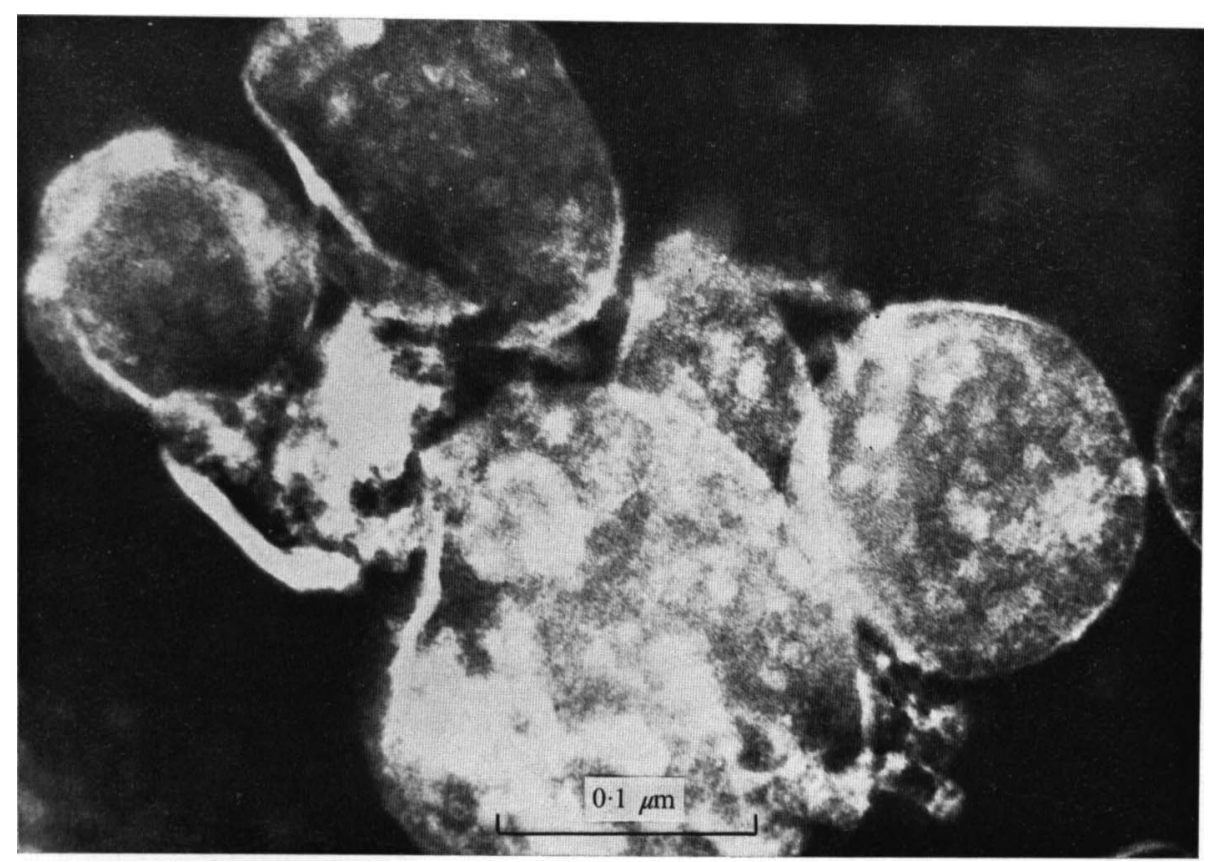

Fig. 3. Electron micrograph of fraction $\mathbf{P}_{40}$. A portion of the particulate preparation $\mathbf{P}_{40}$ was fixed with $4 \%$ glutaraldehyde and negatively stained with phosphotungstic acid.

\section{Mannose incorporation}

The toluene-treated preparation also catalyses the transfer of mannose from GDP$\left[\mathrm{U}-{ }^{14} \mathrm{C}\right] \mathrm{mannose}$ to endogenous acceptor(s) in situ. When both sugar nucleotides were added (Table 3) the transfer of either sugar was unaffected by the presence of the other, which suggests that the two reactions involve different enzymes and different acceptor molecules. 


\section{Table 3. Transfer of radioactivity from $U D P-\left[U-{ }^{14} C\right] g l u c o s e$ and $G D P-\left[U-{ }^{14} C\right]$ mannose to endogenous acceptors in situ}

Toluene-treated cells $(2 \mathrm{mg})$ were incubated with either UDP-[U-14C]glucose or GDP-[U-14C]mannose. After $30 \mathrm{~min}$ at $30{ }^{\circ} \mathrm{C}$, the reaction was stopped with one volume of $10 \% \mathrm{TCA}$. The precipitates were collected on glass fibre discs and counted.

\begin{tabular}{|c|c|c|c|c|}
\hline \multicolumn{2}{|c|}{ UDP-[U-14 C]glucose } & \multicolumn{2}{|c|}{ GDP-[U-14C]mannose } & \multirow{2}{*}{$\begin{array}{l}\text { Incorporated radioactivity } \\
(\mathrm{cpm})\end{array}$} \\
\hline pmol & $\mathrm{nCi}$ & pmol & $\mathrm{nCi}$ & \\
\hline 210 & 24 & - & 一 & I 175 \\
\hline 210 & 24 & $1 \cdot 3 \times 10^{4}$ & - & I I53 \\
\hline 210 & 24 & 130 & 10 & 1800 \\
\hline 一 & - & 130 & 10 & 765 \\
\hline $2 \cdot 1 \times 10^{4}$ & 一 & 130 & IO & 783 \\
\hline
\end{tabular}

\section{Other aspects}

The reaction proceeded without added primers, but since the enzymic preparation contains $\beta$-glucan the presence of an endogenous primer could not be ruled out. Addition of $\beta$-( $\mathrm{I} \rightarrow 3)$ glucan (laminarin), $\beta$ - $(\mathrm{I} \rightarrow 6)$ glucan (pustulan), insoluble yeast glucan, or partially hydrolysed yeast glucan (Manners et al. 1973) to the standard reaction mixture did not affect the amount of radioactivity incorporated. We partially hydrolysed ${ }^{14} \mathrm{C}$-labelled yeast glucan, obtaining mainly a mixture of glucose and laminaribiose. When this mixture was added to the preparation in situ, none of the added ${ }^{14} \mathrm{C}$ was incorporated. It was considered possible that transglucosylation might have occurred, by analogy with the sucrose transglucosylase activity found in the strains of Leuconostoc which produce $\alpha-(I \rightarrow 6)$ glucan.

Neither L-sorbose, 2-deoxy-D-glucose, glucose nor bacitracin affected the amount of $\left[\mathrm{U}-{ }^{14} \mathrm{C}[\right.$ glucose transferred in these experiments. ATP ( $\mathrm{I} \mathrm{mM}$ ), reduced the amount of radioactivity incorporated by $50 \%$.

\section{Wall turnover}

During exponential growth, Gram-positive micro-organisms show wall turnover which accounts for almost $50 \%$ of the wall material per generation (Fiedler \& Glaser, 1973). This turnover, as has been pointed out by several workers, suggests that wall construction includes both lytic and biosynthetic activities. Saccharomyces cerevisiae is a Gram-positive eucaryotic organism, and wall turnover was studied after labelling the cells for $4 \mathrm{~h}$ with $\left[\mathrm{U}-{ }^{14} \mathrm{C}\right] \mathrm{glucose}$ (see Methods). Pulse-chase experiments on the wall material showed that less than $5 \%$ of the $\beta$-glucan and mannan of the wall was released into the growth medium during $2 \mathrm{~h}$ at $30^{\circ} \mathrm{C}$ (mean generation time under these conditions, $90 \mathrm{~min}$ ). This may indicate that wall turnover is less active than in Gram-positive bacteria. It cannot be ruled out, however, that partially degraded material might be used again as building blocks, or that the lytic activities produce single cuts in the wall mesh which allow the addition of new glucan subunits. In either event the release of radioactivity from the yeast might not be detected.

\section{Role of lipids}

The transfer of mannose, from GDP-mannose, as in many other systems (for a review see Lennarz \& Scher, I972), proceeds through a lipid carrier, which has been characterized as a phosphodiester of one or more sugars and a polyprenol. We have investigated the possible involvement of a lipid intermediate in the biosynthesis of yeast glucan from UDP-glucose by the toluenized preparation and by the particles $\left(\mathbf{P}_{\mathbf{1 0}}+\mathbf{P}_{\mathbf{4 0}}\right)$, but were unable to detect radioactive lipids in the former preparation. When the particles were used, signi- 
ficant amounts of label could be extracted with chloroform-methanol $(2: I, v / v)$. Silicic acid chromatography of the extract resulted in the quantitative elution of the radioactivity with acetone, which indicates that glycolipids rather than phospholipids had been formed (Lennarz \& Scher, 1972). Clearly, this does not mean that lipid carriers play no part in glucan biosynthesis. However, similar experiments, carried out with GDP-[U-14 $\mathrm{C}]-$ mannose and the particles, produced significant amounts of radioactive lipids.

The polymer(s) synthesized by permeabilized yeast cells include alkali and acid-insoluble material that appears to be the $\beta-(\mathrm{I} \rightarrow 3)$ glucan of the wall. The data presented in Table $\mathrm{I}$ and Figs. 2 and 3 suggest that the glucan synthetase system is located in cellular membranes. But it is interesting that ostensibly intact yeast cells incorporated a small amount of ${ }^{14} \mathrm{C}$. Staehelin (1966) found that the small particles present in the outer surface of Chlorella plasmalemma migrate to the central region of the wall where cellulose microfibrils seem to be formed from them. Wang \& Bartnicki-García (1966) reported that in Phytophtora cinnamomi, most of the glucan synthetase activity is associated with the hyphal walls. On the basis of what is known about yeast mannan formation and of the findings reported in this paper, we postulate that the $\beta$-glucan of the yeast cell wall might be synthesized as follows: Glucan subunits are formed in vesicles in the cytoplasm, which fuse with the plasmalemma by reverse pinocytosis to produce external glucan subunits. These give rise to the three-dimensional framework of the wall. Activity of either hydrolytic or transglucosylating enzymes might initially be needed to produce openings in the structural glucan mesh.

\section{REFERENCES}

Abd-El-Al, A. T. \& Phaff, H. J. (1969). Purification and properties of endo- $\beta$-glucanase in the yeast Hanseniaspora valbyensis. Canadian Journal of Microbiology r5, 697-701.

Agrawal, B. B. L. \& GoldsteIn, I. J. (1965). Specific binding of concanavalin A to cross-linked dextran gels. Biochemical Journal 96, $23 \mathrm{C}-25 \mathrm{C}$.

Bacon, J. S. D., FARMer, V. C., Jones, D. \& TAYLor, I. F. (1969). The glucan components of the cell wall of baker's yeast (Saccharomyces cerevisiae) considered in relation to its ultrastructure. Biochemical Journal II4, 557-567.

BARRAS, D. R. (1972). A $\beta$-glucan endo-hydrolase from Schizosaccharomyces pombe and its role in cell wall growth. Antonie van Leeuwenhoek 38, 65-80.

Elorza, M. V. \& Sentandreu, R. (1969). Effect of cycloheximide on yeast cell wall synthesis. Biochemical and Biophysical Research Communications 36, 74I-747.

FiedLeR, F. \& GLASER, L. (1973). Assembly of bacterial cell walls. Biochimica et biophysica acta 300, 467-485.

GACHELIN, G. (1969). A new assay of the phosphotransferase system in Escherichia coli. Biochemical and Biophysical Research Communications 34, 382-387.

GHUYSEN, J. M. (1968). Use of bacteriolytic enzymes in determination of wall structure and their role in cell metabolism. Bacteriological Reviews 32, 425-464.

Johnson, B. F. (1968). Lysis of yeast cell walls induced by 2-deoxyglucose at their sites of glucan synthesis. Journal of Bacteriology 95, I I69-I 172.

LAMPORT, D. T. A. (1970). Cell wall metabolism. Annual Review of Plant Physiology 21, 235-270.

LenNARZ, W. J. \& SCHER, M. G. (1972). Metabolism and function of polyprenol sugar intermediates in membrane-associated reactions. Biochimica et biophysica acta 265, 4I 7-44I.

Mahadevan, P. R. \& MahadKaR, U. R. (1970). Role of enzymes in growth and morphology of Neurospora crassa: cell-wall-bound enzymes and their possible role in branching. Journal of Bacteriology, ror, 94 I-947.

Manners, D. J., Masson, A. J. \& Patterson, J. C. (1973). The structure of a $\beta$-(I $\rightarrow 3$ )-D-glucan from yeast cell walls. Biochemical Journal 135, 19-30.

Matile, Ph., Cortat, M., Wiemken, A. \& Frey-Wyssling, A. (I97I). Isolation of glucanase-containing particles from budding Saccharomyces cerevisiae. Proceedings of the National Academy of Sciences of the United States of America 68, 636-640.

NorthCote, D. H. \& HoRne, R. D. (I95I). The chemical composition and structure of the yeast cell wall. Biochemical Journal 5I, 232-236. 
Reese, E. T., Parrish, F. W. \& Mandels, M. (I962). $\beta$-D-I,6-Glucanases in fungi. Canadian Journal of Microbiology 8, 327-334.

ReEVES, R. E. \& Sols, A. (I973). Regulation of Escherichia coli phosphofructokinase 'in situ'. Biochemical and Biophysical Research Communications 50, 459-466.

Sentandreu, R. \& Elorza, M. V. (1973). The biosynthetic pathway of yeast mannan glycoproteins. In Yeast, Mould and Plant Protoplasts, pp. 187-204. Edited by J. R. Villanueva, I. García Acha, S. Gascón and F. Uruburu. London and New York: Academic Press.

Sentandreu, R. \& Lampen, J. O. (I97I). Participation of a lipid intermediate in the biosynthesis of Saccharomyces cerevisiae LK2GI 2 mannan. FEBS Letters 14, I09-I 13.

Sentandreu, R. \& Northcote, D. H. (1968). The structure of a glucopeptide isolated from the yeast cell wall. Biochemical Journal ro9, 419-432.

Sentandreu, R. \& Northcote, D. H. (1969). Yeast cell wall synthesis. Biochemical Journal Ir5, 23 I-240.

Serrano, R., Gancedo, J. M. \& Gancedo, C. (1973). Assay of yeast enzymes 'in situ'. A potential tool in regulation studies. European Journal of Biochemistry 34, 479-482.

Staehelin, A. (1966). Die Ultrastruktur der Zellwand und des Chloroplasten von Chlorella. Zeitschrift für Zellforschung und mikroskopische Anatomie 74, 325-350.

Stewart, T. S. \& Ballou, C. E. (1968). A comparation of yeast mannans and phosphomannans by acetolysis. Biochemistry 7, 1855-1863.

WANG, M. C. \& BARTNICKI-GARCIA, S. (I966). Biosynthesis of $\beta-(\mathrm{I} \rightarrow 3)$ and $\beta-(\mathrm{I} \rightarrow 6)$ linked glucan by Phytophthora cinnamomi hyphal walls. Biochemical and Biophysical Research Communications 24, 832-837. 